\title{
PATHOGENETIC SUBSTANTIATION OF THERAPEUTIC AND PREVENTIVE MEASURES IN SEVERE CORONAVIRUS INFECTION
}

Alexey Alexeevich Novikov ${ }^{1}$, Sergey Bolevich ${ }^{1}$, Sergey Ivanovich Vorobjov ${ }^{1}$, Nina Aleksandrovna Novikova ${ }^{1}$, Denis Dmitrievich Bolotov ${ }^{2}$ and Andrey Vladimirovich Yakovchenko ${ }^{1}$

${ }^{1}$ I.M. Sechenov First Moscow State Medical University, Moscow, Russia

${ }^{2}$ Russian Medical Academy of Continuing Professional Education, Moscow, Russia

\author{
PATOGENETSKI DOKAZ O TERAPEUTSKIM I PREVENTIVNIM \\ MERAMA KOD OZBILJNE INFEKCIJE KORONAVIRUSOM \\ Alexey Alexeevich Novikov ${ }^{1}$, Sergey Bolevich ${ }^{1}$, Sergey Ivanovich Vorobjov ${ }^{1}$, Nina Aleksandrovna Novikova ${ }^{1}$, \\ Denis Dmitrievich Bolotov ${ }^{2}$ i Andrey Vladimirovich Yakovchenko ${ }^{1}$ \\ ${ }^{1}$ I.M. Sečenov Prvi moskovski državni medicinski univerzitet, Moskva, Rusija \\ ${ }^{2}$ Ruska medicinska akademija za kontinuiranu profesionalnu edukaciju, Moskva, Rusija
}

\begin{abstract}
The basis of coronavirus disease is an infectious process, accompanied by a varying degree of activity of pathological processes. Based on the study of the pathological course of infection, modern approaches to the treatment and prevention of complications of coronavirus infection are presented. The main strategic pathogenetic direction in the creation of effective programs for the treatment of COVID-19, as well as the prevention of fatal complications, should be a set of measures enhancing permissive regulatory influences and events. Endothelium, being a source of inflammatory mediators and a transducer of their regulatory effects on the vascular tone, is involved in the development and alternation of vascular reactions, changing the volume of perfusion. The main mechanism for the development of endothelial dysfunction and damage is associated with an imbalance between the generation of reactive oxygen species and the power of the antioxidant defense system. Any measures to protect the endothelium, reducing the severity of microcirculatory disorders and hypoxia, will have a therapeutic and preventive effect on fatal complications. In this regard, in the treatment of COVID-19, the use of synthetic gas transport preparations based on perfluorocarbon nanodispersed emulsions with a clinical effect directed at once to several pathogenetic links underlying the progression of COVID-19 disease can be quite effective. The necessity of a comprehensive effect on pathogenesis using sanogenetic principles of treatment, allowing influencing the speed and time of onset of resolution of inflammation, which can reduce the number of complications and deaths of the disease, is substantiated.
\end{abstract}

Keywords: COVID-19; inflammatory mediators, endothelium damage, treatment; prevention.

\section{SAŽETAK}

Osnova bolesti izazvane koronavirusom je infektivni process praćen različitim stepenom aktivnosti patoloških procesa. Zasnovan na proučavanju patološkog toka infekcije, savremeni pristupi lečenja i prevencije komplikacija nastalih usled infekcije koronavirusom su predstavljeni. Glavni strateški patogenetski pravac u kreiranju efikasnih programa za lečenje COVID-19, kao i za sprečavanje fatalnih komplikacija, trebalo bi da bude niz mera koje pospešuju dozvoljene regulatorne uticaje $i$ događaje. Endotel, izvor inflamatornih medijatora i transduktor njihovih regulatornih efekata na vaskularni tonus je uključen u razvoj $i$ izmenu vaskularnih reakcija, menjajući volumen perfuzije. Glavni mehanizam za razvoj endotelne disfunkcije i oštećenja je povezan sa neravnotežom između stvaranja reaktivnih vrsta kiseonika i snage antioksidacionog odbrambenog sistema. Bilo koje mere da se zaštiti endotel, smanjujući ozbiljnost mikrocirkulatornih poremećaja i hipoksije, će imati terapeutski i preventivni efekat na fatalne komplikacije. U ovom pogledu, u lečenju COVID-19, upotreba sintetičkih gasnih transportnih preparata, zasnovanih na perfluorokarbonskih nanodisperzovanih emulzija sa kliničkim dejstvom usmerenih neposredno na nekoliko patogenetskih veza koje su u osnovi progresije COVID-19 bolesti, može biti sasvim efikasna. Potreba sveobuhvatnog dejstva na patogenezu korisćenjem sanogenetskih principa lečenja, omogućavajući uticaj na brzinu $i$ vreme početka rezolucije inflamacije, što može da smanji brojne komplikacije i smrt usled bolesti, je potvrđena.

Ključne reči: COVID-19, inflamatorni medijatori, oštećenje endotela, lečenje, prevencija.

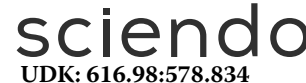

Ser J Exp Clin Res 2020; 21 (3): 189-199

DOI: $10.2478 /$ sjecr-2020-0043 


\section{ABBREVIATIONS}

ACE - angiotensin-converting enzyme;

AM-1 - endothelial-leukocyte type 1 adhesive molecule;

ARDS - acute respiratory distress syndrome;

CO - carbon monoxide;

COVID-19 - Coronavirus Disease;

DHA - docosahexaenoic acid;

EC - endothelial cells;

ED - endothelial dysfunction;

EL ICAM - integral intercellular adhesive molecules;

EPA - eicosapentaenoic acid;

ESL - endothelial surface plate;

ESR - erythrocyte sedimentation rate;

FAT - platelet activation factor;

H2S - hydrogen sulfide;

IL - interleukin;

\section{INTRODUCTION}

The basis of coronavirus disease is an infectious process, accompanied by a varying degree of activity of pathological processes. Among the main hallmarks of pathogenesis of coronavirus infection, there are inflammation, endothelial dysfunction, hypoxia, metabolic disorders, microcirculatory disorders, as well as impaired function of organs and systems (respiratory, cardiovascular, excretory, liver, digestive, nervous, endocrine, etc.). Inflammation includes a local reaction and a systemic inflammatory response. Endothelial dysfunction, as a component of the inflammatory response, is simultaneously a key link in pathogenesis, and a link between inflammation and other pathological processes (1). These pathological processes unfold and reach their greatest severity during the peak of the disease, determining the main clinical manifestations, consequences and outcome of the infectious process. During this period of time, as a rule, the action of the etiological factor is completed, diagnostics have already been carried out and treatment of patients begins (2).

Modern strategies for treating infections imply killing bacteria and/or inhibiting their growth, and in the case of viral infections, the inhibition of viral replication. The implementation of such strategy during the peak of the disease has prophylactic importance in the prevention of generalization of the infection and the occurrence of complications, but, on the other hand, it is not very effective in the treatment of developed infections. At the same time, therapeutic measures should aim to suppress inflammation and key pathogenetic mechanisms underlying the dysfunction of organs and systems due to this inflammatory process or other pathological processes aggravating the patient's condition (3).
LC - leukotrienes;

NO - nitric oxide;

NO3 - peroxynitrite;

NOD - like - nucleotide-binding oligomerization

domain-like;

PG - prostaglandins;

PRRs - pattern recognition receptors;

ROS - reactive oxygen species;

SARS-CoV2 - severe acute respiratory syndrome coronavirus-2;

SPMs - specialized pro-resolving mediators;

SPON - multiple organ failure syndrome;

TMPRSS2 - transmembrane serine protease 2;

VC AM-1 - vascular cell adhesive type 1 molecule.

\section{PATHOGENETIC MECHANISMS UNDERLYING SARS-COV2 INFECTION}

To date, a consensus has been formed that the penetration of SARS-CoV2 virus (severe acute respiratory syndrome coronavirus-2) into cells is mediated by its interaction with ACE2 receptor protein (angiotensin-converting enzyme 2), as well as with transmembrane serine protease 2 (TMPRSS2) and cathepsin L, which allow the virus to enter the cell and cause it to produce new virions (4-7).

ACE2 is a membrane-bound protein-enzyme, cleaving one amino acid from the C-terminal part of angiotensin II, it turns it into a vasodilator angiotensin 1-7, performing a counter-regulatory function with respect to ACE1, which is involved in the formation of angiotensin II (8). It should be noted that this ACE2 receptor protein is widely represented in the human body, and is found not only in the pulmonary epithelium, but also in endotheliocytes, smooth muscle cells, myocardium, kidneys, gastrointestinal tract, bone marrow, spleen and other organs and tissues. It is believed that such wide representation of ACE2 allows the variety of clinical manifestations of SARS-CoV2 infection and the possibility of developing multiple organ failure syndrome as a complication $(5,9,10)$.

It is extremely interesting that the ACE2 gene activity could be stimulated by interferons. This may explain the sudden aggravation of the course of the disease, for example, due to an avalanche-like increase in the lung damage and the occurrence of a cytokine storm (11). 


\section{ROLE OF ENDOTHELIAL CELLS IN SARS-COV2 INFECTION}

However, this variety of symptoms may also form for another reason. The explanation, built on the basis of the ubiquity of receptor proteins, does not take into account differences in their availability to the action of the virus, the possibility of indirect cell damage, and, consequently, regional characteristics of resistance and reactivity. The number of potential target cells also matters, which undoubtedly affects the likelihood of infection. In this regard, it should be noted that in addition to the pulmonary epithelium, one of the most likely targets for damage are endothelial cells. These are made not only by the high prevalence in the body (occupying the $2^{\text {nd }}$ place after muscle cells), but also by their strategic location (on the border of two media, between the blood and tissue), as well as the importance of functions of the endotheliocyte for the task of ensuring the transport of substances between the blood and tissues $(2,5,8,12)$.

The following list can give some idea of the multiplicity of endothelial functions. The main role of the endothelium is to maintain homeostasis by regulating the following processes in the body:

1. Vascular tone (the balance of vasoconstriction and vasodilation);

2. The anatomical structure of blood vessels (potentiation and inhibition of proliferation factors);

3. Hemostasis (potentiating and inhibition of coagulation, fibrinolysis and platelet aggregation factors);

4. Local inflammation (the development of pro-inflammatory, anti-inflammatory and repairing factors);

5. The development of a systemic inflammatory response (reactions of the acute phase of inflammation), which includes responses of the functional systems of the body at the neuroendocrine, hematopoietic, metabolic and hepatic levels (the examples of such physiological changes are fever, drowsiness and anorexia, hematopoietic shifts, including anemia, leukocytosis and thrombocytosis, while osteoporosis and decreased gluconeogenesis are the examples of metabolic changes). The combination of the above phenomena is included in the prodromal syndrome and is accompanied by other deviations in the plasma concentration of proteins of the acute phase of inflammation, for example, serum amyloid A and C-reactive protein;

6. Vascular support (angiogenesis and angioregression);

7. Formation of stroma of a tissue or organ (endothelialmesenchymal transition, formation and apoptosis of myofibroblasts, synthesis and destruction of collagen) $(13,14)$.

Based on this list, one can approximately imagine the entire possible variety of clinical manifestations and consequences associated with the endothelial damage, including the infectious inflammation, for example, with the coronavirus disease (15).

\section{SYSTEMIC MANIFESTATIONS OF SARS-COV2 INFECTION}

Given the diversity and importance of the vital functions of endotheliocytes, as well as the systemic nature of disorders that occur when they are massively defeated, it can be confidently stated that the endothelial dysfunction plays a key role in the pathogenesis of developing acute respiratory distress syndrome (ARDS) and multiple organ failure syndrome, and also participates in the development of subsequent complications in the form of fibrotic dysplasia and functional impairment $(1,2,12)$.

One of the most formidable complications of a coronavirus pandemic, which WHO called the 2019 Coronavirus Disease (COVID-19), is a severe acute coronavirus respiratory syndrome 2 , often fatal (16). Clinicians noted that most patients experienced a sudden deterioration in their health in the later stages of the disease or during the onset of recovery. The acute respiratory distress syndrome (ARDS) and multiple organ failure quickly occurred, the combination of which in many cases was fatal $(5,17)$.

The delayed occurrence of complications is evidenced by the data on the absence of disorders of the cardiovascular and urinary systems upon admission of patients to the hospital. In this case, acute damage to the kidneys and myocardium usually occurred 8-14 days after the onset of symptoms and was the precursor of an unfavorable prognosis of the course of the disease $(5,18)$.

Several factors which increase the risk of death have been identified among the adults in Wuhan hospitalized due to COVID-19. Laboratory abnormalities at the admission included lymphopenia, increased levels of C-reactive protein, lactate dehydrogenase, highly sensitive cardiac troponin I, liver transaminases and D-dimer (48). Some studies have reported elevated levels of other inflammatory markers, such as IL-6, ferritin, and ESR (5).

Signs of negative dynamics were also recognized as higher body temperature upon the admission, increased respiratory rate, decreased albumin levels, and increased blood coagulation. In addition to laboratory indicators and basic vital signs, a negative prognosis was evidenced by old age, chronic diseases of the cardiovascular and respiratory systems, obesity, diabetes mellitus, chronic kidney disease, and others. Sepsis was diagnosed in half of these patients (18-21).

As you know, the basis of sepsis is the systemic inflammatory response syndrome (SIRS), which is a hyperergic systemic reaction of the whole organism to an infectious irritant. It is a complex of the systemic phenomena that occurs under the action of cytokines and is also known as the "acute phase" or "preimmune response" response. Despite the fact that this reaction is protective and adaptive in origin, its excessive nature in the case of sepsis, when the so-called unregulated cytokine storm occurs, can cause massive 
irreversible dysfunction of vital organs and even lead to death (22-24).

These manifestations of the systemic inflammatory response usually include fever, arthralgia and myalgia, sleep disturbance, decreased appetite, changes in the functioning of physiological systems (respiration, blood circulation, digestion, urination, etc.), as well as changes in the laboratory parameters: increased ESR, leukocytosis, dysproteinemia (Creactive protein, amyloid $\mathrm{A}$ and $\mathrm{P}$, transferrin, ceruloplasmin, immunoglobulins, enzymes, etc.). Considering the mechanisms of the occurrence and development of these manifestations, we can conclude that one of the central roles here is played by ED, which develops under the influence of cytokines. ECs involved in the formation of cytokines also contribute both to the development of general inflammatory reactions and, ultimately, to irreversible dysfunction of vital organs and SPON (multiple organ failure syndrome) $(1,2,24-$ 27).

To date, the evidence has been obtained that the adverse development of coronavirus infection is due to the development of a cytokine storm $(5,18,28)$.

This cytokine disturbance correlates with the severity of endothelial dysfunction, however, the causality of this relationship has not been established, obviously due to the presence of both direct and reverse causal relationships, and also because these phenomena develop in parallel within the framework of the general inflammatory process $(2,15,22$, 28).

A progress in the study of humoral mediators controlling the inflammation process has led to a change in the outlook on the resolution of inflammation, which, in contrast to previous ideas, is an active rather than a passive process. The main biological activities and functions of pro-resolving mediators are determined, which include:

1. Limitation and termination of penetration of polymorphonuclear neutrophils into tissues;

2. Reducing damage to the surrounding tissues by phagocytes;

3. Reducing the resolution interval;

4. Strengthening of macrophage phagocytosis and efferocytosis;

5. Counteraction to pro-inflammatory chemical mediators (platelet activation factor - FAT, leukotrienes - LC, prostaglandins - PG);

6. Increase in anti-inflammatory mediators (IL-10 and others);

7. Increased destruction of microbes and their clearance by innate immune cells;

8. Improving tissue regeneration.

Thus, "Resolution" is a highly coordinated process at different hierarchical levels (from molecular to tissue, and possibly to systemic), which serves to repair and regenerate damage in organs and tissues, as well as to normalize their functions (29-31).

In the process of acute inflammation, three stages can be distinguished (Figure 1). If we correlate and analyze in chronological sequence all these three stages of the infection process with the adverse development of COVID-19, then we can draw the following conclusions:

Figure 1. A review of the cellular and molecular processes that control inflammation and its resolution.

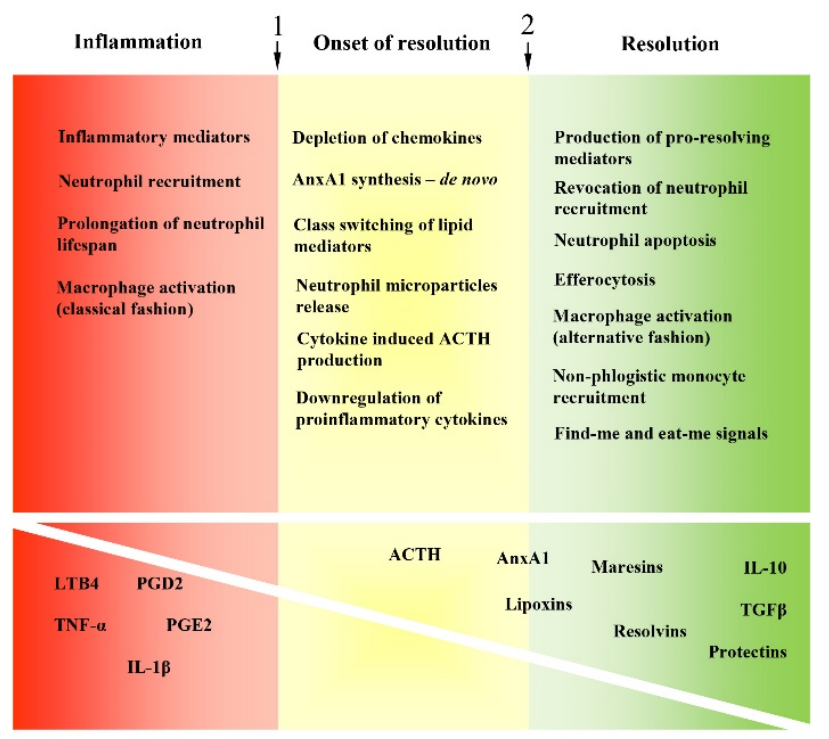

(Quoted from Michelle A. Sugimoto, Lirlândia P. Sousa, Vanessa Pinho, Mauro Perretti, Mauro M. Teixeira, Resolution of Inflammation: What Controls Its Onset?, Front Immunol. 2016; 7: 160., doi: 10.3389/fimmu.2016.00160 (32)).

1. The period of acute inflammation corresponds to the periods of the height of the disease and recovery. In this case, the onset of inflammation and the onset of resolution correspond to the height of the peak, and the period of recovery corresponds to the resolution and restoration of homeostasis;

2. The signs of unfavorable course of the disease are: higher temperature, leukocytosis, lymphocytopenia, creatinine, lactate dehydrogenase, high sensitivity troponin I, Ddimer and increased markers of inflammation, such as ferritin, IL-6 and procalcitonin, hypercoagulation and myocardial damage, as risk factors for death, they occur at the beginning of the height of the disease, correlate with the severity of the disease, and also progress throughout the disease (Fig. 1 arrow No. 1) (18);

3. The time period during which a change in the course of events can occur (either recovery, or the occurrence of complications and aggravation of the condition) falls at the end of the period of the disease height, before the recovery stage (in Fig. 1 arrow No. 2). This is consistent with the theoretical 
model for the progression of COVID-19 disease described previously $(5,28)$.

Thus, in our opinion, the time-varying balance of pro-inflammatory and pro-resolving mediators that are produced during the inflammation is crucial for determining the fate of an inflammatory reaction. From the review, it becomes clear that one of the possible reasons for the development of a cytokine storm with a hyperergic uncontrolled systemic inflammatory response may be the absolute or relative insufficiency of pro-resolving factors existing or arising in the development process. This insufficiency can occur due to the delay in switching the synthesis of pro-inflammatory mediators to pro-permissive ones. It has traditionally been believed that excessive production of pro-inflammatory mediators underlies chronic inflammation, but a growing body of evidence supports the notion that disturbances in endogenous pro-resolving mechanisms can be an equally important factor (3335).

We believe that three potential targets should be considered:

1) Cytokines;

2) Specialized pro-allowing mediators;

3) Endotheliocytes and related functional systems, according to which the main directions for the development of therapeutic strategies can be formed.

Attempts to influence the cytokine pathogenesis of COVID-19 have been shown to be effective. SARS-CoV-2 induces excessive and prolonged cytokine/chemokine reactions in some infected people. A cytokine storm causes the acute respiratory distress syndrome or multiple organ dysfunction, which leads to a sharp aggravation of the condition and death. It is commonly believed that timely control of a cytokine storm at its early stage by immunomodulators and cytokine antagonists, as well as reduction of pulmonary infiltration by inflammatory cells, is the key to increasing the treatment efficiency and reducing mortality (28).

But the severity and duration of inflammation depend on competing physiological processes, namely, on pro-inflammatory mechanisms that enhance the inflammation and endogenous inhibition programs, which in turn control the resolution of inflammation (36).

However, the anti-inflammatory effect is not the same as the resolution, which involves specialized pro-resolving mediators (SPMs) in the activation of non-logistic reactions and programs for resolving inflammation, and ends with the restoration of a structure and function with a return to the initial homeostasis and formation of immunological memory.

These pro-inflammatory mediators actively stop the production of pro-inflammatory mediators, but also immediately stimulate phagocytosis by macrophages of both apoptotic cells and bacteria, increase the output of phagocytes from inflammation sites, regulate apoptosis of stab leukocytes, increase the scavenger capture of chemokines, and stimulate tissue repair and regeneration (33).

It must be remembered that cytokines, like other inflammatory mediators, are only a part of the effector link of the launched and implemented genetic program of inflammation, they activate and control protective and adaptive reactions aimed at delimiting and eliminating the phlogogenic factor. Cancellation or blocking of their action reduces the severity or cancels the ongoing protective-adaptive phlogistic reaction, including at the stage of resolution and recovery, which can reduce the positive biological significance of inflammation until complete disappearance $(28,37)$.

This may be accompanied by a decrease in anti-infectious resistance, generalization of the process, the development of immunosuppression and chronicity of the disease, as well as violation of the repair and regeneration processes, which can manifest itself as the development of fibrosis, pathological angiogenesis, and, as a consequence, violation of the function of an organ or tissue. A number of studies have revealed that excessive acute inflammation and chronic unresolved inflammation were associated with severe and deadly diseases of the human lung, including ARDS, asthma, cystic fibrosis, and chronic obstructive pulmonary disease $(33,38)$.

The causes of damage and/or delayed response mechanisms may be due to several factors that may contribute to unsuccessful resolution. For example, a decrease in food intake of $\omega-3$ essential fatty acids (EPA eicosapentaenoic acid, DHA docosahexaenoic acid), genetic polymorphisms of enzymes involved in the biosynthesis of specialized resolving mediators or SPM receptors, dysfunctional SPM receptors or a decrease in their expression, abnormal signaling inside as well as toxic drugs $(34,35)$.

Also, various disorders on the part of cells and their interactions involved in the synthesis of pro-resolving mediators and in the resolution process itself should be considered (39).

Thus, the main strategic pathogenetic direction in the creation of effective programs for the treatment of COVID-19, as well as the prevention of fatal complications, should be a set of measures enhancing permissive regulatory influences and events. To date, the precursors of PSD $\omega-3$ irreplaceable fatty acids (EPA eicosapentaenoic acid, DHA docosahexaenoic acid) in acute and chronic inflammatory processes with a positive result have been studied in experiments and in clinical practice (31).

Synthetic analogues of lipoxins and resolvines already exist, which are undergoing clinical trials (40-42).

Along with lipid mediators, peptides, proteins and gases also stimulate resolution. For example, endogenous gases such as $\mathrm{NO}, \mathrm{H} 2 \mathrm{~S}$, and CO play a positive role in resolving inflammation (34). 
Carbon monoxide, endogenously produced by the hemoxygenase enzyme system, has become a promising gaseous therapeutic agent that has a protective effect against inflammation, oxidative and mechanical stress and apoptosis, thus potentially limiting the acute lung damage. Numerous studies using in vivo and in vitro models have demonstrated the anti-inflammatory and resolving, anti-apoptotic and antiproliferative properties of carbon monoxide in the lungs when used in low doses before or during ischemia-reperfusion, transplantation, sepsis, hyperoxia or mechanical ventilation, which is called ventilation damage. The molecular mechanisms that are affected by carbon monoxide are still not fully understood (43- 45).

The biological actions of these new mediators in the fight against inflammation are different from modern therapeutic agents. Indeed, while drugs used in clinical practice are designed to inhibit inflammation and block leukocyte recruitment, PSD acts by counteracting the production of pro-inflammatory mediators (cytokines, chemokines and inflammatory eicosanoids), limiting the leukocyte infiltration and facilitating the switching of the leukocyte phenotype. Therefore, these substances do not prevent inflammation, but rather strengthen the regulatory control, preventing its uncontrolled course and, thus, contribute to its cessation. It has been demonstrated that PSDs increase survival and help resolve inflammation, as well as some human diseases associated with dysregulation of the PSD pathways, including PSD generated from DHA and EPA $(30,35,38)$.

Another way to improve resolution is to use cyclin-dependent kinase inhibitors (46).

In addition, it can be argued with certainty that transfusion of fresh blood plasma of a healthy person will bring significant benefits. it contains various factors, such as microvesicles containing m-RNA, $\alpha$-2-macroglobulin, ulinastatin, potentiating the action of pro-resolving factors, limiting hyperergic inflammation and contributing to its resolution $(28,47,48)$.

At autopsy of the dead from COVID-19, pulmonary fibrosis is usually present. Those, in some cases, abnormal immune mechanisms initiate and contribute to the appearance of pulmonary fibrosis, possibly due to a cytokine storm (49, $50)$.

However, diffuse alveolar damage, which is the defining feature of the acute respiratory distress syndrome, was a characteristic histological feature in fatal cases of COVID-19 with the additional observation of microvascular thrombosis $(50,51)$.

The basis of these structural transformations is a change in the functional activity of many cells: endotheliocytes, pericytes, fibroblasts, epithelial cells, macrophages, lymphocytes and so on. The activation of these cells leads, together with the vascular neoplasm, increased permeability of the wall and edema, to emigration with tissue infiltration by inflammatory cells, an increase in the number and activity of fibroblasts with the development of fibrosis and other degenerative-destructive changes. As a result, a new tissue is formed that does not provide the necessary function of the tissue, which differs from normal in its structural and functional characteristics. We believe that enhancing the action of pro-resolving mediators that act on many key links of inflammation and are involved in restoring the structural and functional homeostasis will be the most effective way to prevent the occurrence of such complications $(52,53)$.

Finally, the endothelial dysfunction, which is simultaneously one of the key components of inflammation, should be considered the third target for the formation of therapeutic strategies. The enormous role of endothelium in the initiation, development, and completion of inflammation is known. The endothelium, which has many diverse receptors capable of recognizing pathogenicity patterns of Pattern recognition receptors (PRRs): Pathogen-associated molecular pattern (PAMP) and Damage-associated molecular patterns (DAMP), i.e. of all types of toll-like receptors, scavenger receptors, integrins, selectins, nucleotide-binding oligomerization domain-like receptors (NOD-like receptors), etc., is itself the target for phlogogenic factors, it is able to initiate an inflammatory response, and it also recruits immunocompetent cells acting as an antigen-presenting cell secreting pro-inflammatory cytokines and chemokines (54-56).

The endothelium, being a source of inflammatory mediators and, at the same time, a transducer of their regulatory effects on the vascular tone, is involved in the development and alternation of vascular reactions, changing the volume of perfusion (57). As the organizer and regulator of extracorporeal transport, the endothelium affects the volume and composition of exudate (58). Using adhesive molecules and chemoattractants, the endothelium determines the sequence, mass and composition of emigrating cells, and therefore the composition of cell infiltrate (59-61). It participates in resolving inflammation due to the development of anti-inflammatory and pro-resolving factors during interaction with stab leukocytes, macrophages, and other cells $(35,62,63)$, as well as in the restoration of structural and functional tissue and organ homeostasis. This significant role of the endothelium has already been partially evaluated in the treatment of COVID-19 (2).

Based on the foregoing, it can be confidently stated that the severity and consequences of COVID-19, as well as the mortal risk of complications, are due to the prevalence and severity of the endothelial dysfunction.

In this regard, it seems important to carry out therapeutic measures aimed at protecting the endothelium and normalizing its functions, as well as activating the phagocytosis of apoptotic endothelial cells and its subsequent regeneration. For example, it is known that with the development of acute inflammation, the glycocalyx of endothelial cells is damaged first, leading to a violation of the integrity of the endothelial surface plate. As a result, the charge of the vascular wall 
decreases, its adhesive properties increase, and permeability increases. The experience of clinical oral administration of a mixture of low molecular weight glycosaminoglycans in the form of commercially available sulodexide, which allows restoring the thickness of the endothelial surface plate (ESL) in patients with diabetes mellitus, is described. Sulodexide is a mixture of $82 \%$ heparin, $17 \%$ dermatan sulfate and $<1 \%$ chondroitin sulfate and exhibits antithrombotic and profibrinolytic properties, as well as vasculoprotective properties, such as the anti-inflammatory, antioxidant and anti-ischemic effects. The absence of severe side effects, as well as a relatively low price, makes it attractive for use in the treatment and prevention of complications of COVID-19 (64-66).

The main mechanism for the development of the endothelial dysfunction and EC damage is associated with an imbalance between the generation of reactive ROS and the power of the antioxidant defense system. As a result, NO is oxidized with the formation of NO3 (peroxynitrite), the bioavailability of NO decreases, and irreversible nitrosylation of the target proteins occurs, as a result of which a persistent dysfunction of the surrounding cells develops. Suppressing the excessive generation of ROS and restoring balance with the antioxidant defense system will not only protect endothelial cells, but also contribute to normalization of their functioning, restoring antiplatelet, anticoagulant, anti-inflammatory, vasodilator and other functions. Therefore, it is recommended, as a part of the integrated approach to treatment, to use antioxidant defenses (67).

The noticeable and sudden release of many cytokines by the immune system, often called hypercytokinemia or the cytokine storm, has a devastating effect in itself. Cytokines cause type II activation in endotheliocytes, which, in contrast to type I stimulation, does not develop immediately, but after 2-6 hours from the moment of induction by pro-inflammatory factors due to the increased transcription and synthesis of various proteins, cytokines, chemokines and adhesive molecules. During this period, endothelial cells express an endothelial-leukocyte type 1 adhesive molecule (ELAM-1), a larger number of type 1 integral intercellular adhesive molecules (ICAM-1) and Inducible cell adhesion molecule 110 (INCAM-110) with respect to vascular cell adhesive type 1 molecule (VC AM-1), which contributes to the activation, transmigration of neutrophils and tissue infiltration by them, the permeability of the basement membrane increases and plasma leakage sharply increases, stable vasodilation and, as a result, local vascular stasis develops (68-70).

In many infectious diseases, the components of the resulting secondary alteration caused by cytokines may be more pathogenic than the invading microorganisms themselves. Another evidence of the effectiveness of the endothelioprotection strategy was the reduction of harmful effects of the cytokine storm upon activation by the soluble Slit ligand of the endothelium-specific, Robo4-dependent signaling pathway, which strengthens the vascular barrier (71). The consequences of ED, which pose a deadly threat to tissues and organs, are microcirculatory and tissue hypoxia, resulting from venous stagnation of blood, sludge and microthrombosis. The reason for their occurrence is: activation of the endothelium with the appearance of adhesive and proaggregate properties, as well as a shift in the balance between potentiation and inhibition of coagulation factors, fibrinolysis to the procoagulant side, followed by the development of thrombophilia (2).

Therefore, any measures to protect the endothelium, reducing the severity of microcirculatory disorders and the severity of hypoxia, will have a therapeutic and preventive effect on fatal complications. Data on the effectiveness of thromboprophylaxis using low molecular weight heparins, the treatment with fibrinolysis activators have already been accumulated, and recommendations for their use have been published (15, 72-75).

Replacement of dead cells by increasing the mobilization and recruitment of endothelial progenitor cells and other stem/progenitor cells from the bone marrow could be considered as another method of the endothelial protection. Clinical studies have shown that in patients with the organ damage, an increase in the number of circulating endothelial progenitor cells correlated with an improvement in prognosis and survival. In animal experiments, it was found that exogenously administered endothelial progenitor cells or other stem/progenitor cells suppress the systemic and organ inflammation, reduce the organ damage, reduce the endothelial permeability, and improve the sepsis survival $(39,76)$.

In this regard, in the treatment of COVID-19, the use of synthetic gas transport preparations such as Perftoran b Fluoroemulsion III (Russia) based on perfluorocarbon nanodispersed emulsions with a clinical effect directed at once to several pathogenetic links underlying the progression of COVID-19 disease can be quite effective.

The expediency of using gas transportation drugs was caused by the work of Chinese scientists from Sichuan and Yibinsk universities on the effect of COVID-19 on red blood cells, which, as the authors point out, leads to an increase in inflammatory processes and the appearance of frosted glass in the lungs of patients. The authors suggest that COVID-19 can attack human red blood cells by binding to hemoglobin molecules. This leads to a disruption in the transport of oxygen to the organs and tissues of the body and, as a consequence, to hypoxemia. The penetration of viral proteins into red blood cells and binding to hemoglobin leads to "knocking out” of iron ions in blood plasma. In this case, hemoglobin loses its ability to be saturated with oxygen, and the iron ion has a toxic effect, and, as a result, tissue respiration is disturbed with aggravation (aggravation) of oxygen deficiency.

In connection with these studies, it is necessary to cite our work (77) on the elimination of hypoxia in acute autoimmune intravascular hemolysis of erythrocytes caused by a disease such as babesiosis. It is known that in acute intravascular autoimmune hemolysis, both intrinsic and donor erythrocytes are rapidly destroyed with the occurrence of hypoxia and the 
release of a large amount of hemoglobin not associated with haptoglobin into the plasma, due to which free hemoglobin has a pathological effect on all organs. Studies have shown that elimination of hypoxia during intravascular hemolysis of erythrocytes is quite effective with perfluorocarbon hemocorrectors such as Perftoran and Fluoroemulsion III, but not with the help of donor blood and red blood cells.

Gas transportation donor blood substitutes based on perfluorocarbon emulsions are multifunctional drugs with a wide spectrum of action, including the ability to carry any gas (oxygen, carbon dioxide and inert gas - helium oxide, etc.). Due to the nano-dispersed size (50-100 nm), particles of perfluorocarbon emulsions with oxygen physically dissolved in them, are able to penetrate into ischemic tissue sites through spasmodic, sclerotic, partially thrombosed and susceptible vessels; improve blood rheology and microcirculation in tissues with disturbed gas exchange and metabolism of various origins; reduce blood viscosity, increase regional blood flow, promote vascular bed recanalization; increase electronegative charges of the membranes of red blood cells, platelets, and endothelial cells, which increases the suspension stability of blood, improves its rheological characteristics, prevents formation of blood aggregates, activates microcirculation in tissues, provides axial current of blood cells in the vessels, causes decay of false aggregates (in the early stages of critical states), which in turn recanalizes the microvascular bed (79). All these factors are clearly manifested in pathological processes caused by the coronavirus disease.

It is necessary to note other positive properties, which we believe are useful in the noted pathological processes of COVID-19. So, the aforementioned perfluorocarbon gas transport hemoproofreaders have the membrane-stabilizing properties: perfluoro-emulsions stabilize and modify biological membranes, activate oxidative phosphorylation, change the functional properties of red blood cell membranes, increase their charge and resistance to the mechanical trauma, cause platelet disaggregation, red blood cells, and platelets increase the fibrinolytic activity, reduce the concentration of fibrinogen and factor XII; antioxidant properties - eliminate the content of primary and intermediate products of lipid peroxidation of blood plasma lipids, while the intensity of free radical oxidation in erythrocytes and blood plasma decreases with the background of perfluoroemulsion, and the activity of natural antioxidant defense systems increases. They also have detoxification properties: they increase the detoxification function of the liver, induce cytochrome P-450, and affect the natural detoxification system in acute poisoning (80).

Thus, in the absence of effective vaccines and sera in the case of COVID-19 disease, among the considered active treatment strategies, the directions with a complex effect on the pathogenesis using sanogenetic treatment principles are the most attractive.

Such pleiotropy is necessary for the action of the above therapeutic agents. This can be well explained in terms of the theory of functional systems. With the complex organization and the multiplicity of various structures and functions performed by them, there is a single ultimate goal: maintaining homeostasis in the whole organism and in each individual part thereof. The common goal forms the key structures and mechanisms of a single pathogenesis, at which the action of drugs should be aimed.

\section{CONCLUSION}

Apparently, only the simultaneous corrective effect on the numerous signaling pathways that control the course of the inflammatory reaction can significantly affect the execution of this genetically determined program. Obviously, the rate of development and the time of onset of resolving inflammation can be significantly accelerated using the natural signaling pathways that control these sanogenetic mechanisms. It is also safe to say that such therapeutic effects will be most effective, because they synchronize the work of sanogenetic mechanisms and, interacting with each other, potentiate their action, increasing the degree of biological usefulness of the result. At the same time, the methods and methods proposed for testing should be in addition to the already existing types of treatment that have proved their effectiveness. The start time and duration of treatment with these methods depend on the nature and direction of exposure. For example, it makes sense to start the therapy with the precursors of PSD or synthetic analogues of lipoxins and resolvins from the moment of the onset of clinical manifestations, and breathing with the addition of $\mathrm{CO}$ and the infusion of synthetic gas transport preparations from the moment the respiratory failure begins to develop, together with oxygen therapy.

Only correction with multiple regulatory influences that potentiate each other's actions can correct execution of the genetic program, increasing the degree of biological usefulness of the result. At the same time, the methods and methods proposed for testing should be in addition to the already existing types of treatment that have proved their effectiveness.

\section{REFERENCES}

1. Bolotov DD, Novikov AA, Bolevich S, Novikova NA, Yakovchenko AV. Influence of systemic inflammatory response to appearance of new foci of chronic inflammation. Ser J Exp Clin Res. 2020; 21 (1): 3-10.

2. Varga Z, Flammer AJ, Steiger P, Haberecker M, Andermatt R, Zinkernagel AS, Mehra MR, Schuepbach RA, Ruschitzka F, Moch H. Endothelial cell infection and endotheliitis in COVID-19. Lancet. 2020; 395(10234): 1417-18.

3. Md Insiat Islam Rabby. Current Drugs with Potential for Treatment of COVID-19: A Literature Review. J Pharm Pharm Sci. 2020; 23(1): 58-64. 
4. Zhou P, Yang XL, Wang XG, Hu B, Zhang L, Zhang W, Si HR, Zhu Y, Li B, Huang CL, Chen HD, Chen J, Luo Y, Guo H, Jiang RD, Liu MQ, Chen Y, Shen XR, Wang X, Zheng XS, Zhao K, Chen QJ, Deng F, Liu LL, Yan B, Zhan FX, Wang YY, Xiao GF, Shi ZL. A pneumonia outbreak associated with a new coronavirus of probable bat origin. Nature. 2020; 579(7798): 270-3.

5. Atri D, Siddiqi HK, Lang JP, Nauffal V, Morrow DA, Bohula EA. COVID-19 for the Cardiologist: Basic Virology, Epidemiology, Cardiac Manifestations, and Potential Therapeutic Strategies. JACC Basic Transl Sci. 2020; 5(5): 518-36.

6. Hoffmann M, Kleine-Weber H, Schroeder S, Krüger N, Herrler T, Erichsen S, Schiergens TS, Herrler G, Wu NH, Nitsche A, Müller MA, Drosten C, Pöhlmann S. SARS-CoV-2 Cell Entry Depends on ACE2 and TMPRSS2 and Is Blocked by a Clinically Proven Protease Inhibitor. Cell. 2020; 181(2): 271-80.

7. Muus C, et al., Integrated analyses of single-cell atlases reveal age, gender, and smoking status associations with cell type-specific expression of mediators of SARS$\mathrm{CoV}-2$ viral entry and highlights inflammatory programs in putative target cells. bioRxiv. 2020; doi: 10.1101/2020.04.19.049254.

8. Hamming I, Cooper ME, Haagmans BL, Hooper NM, Korstanje R, Osterhaus AD, Timens W, Turner AJ, Navis G, van Goor H. The emerging role of ACE2 in physiology and disease. J Pathol. 2007; 212(1): 1-11.

9. Hamming I, Timens W, Bulthuis ML, Lely AT, Navis $\mathrm{G}$, van Goor H. Tissue distribution of ACE2 protein, the functional receptor for SARS coronavirus. A first step in understanding SARS pathogenesis. J Pathol. 2004; 203: 631-7.

10. Ferrario CM, Jessup J, Chappell MC et al. Effect of angiotensin-converting enzyme inhibition and angiotensin II receptor blockers on cardiac angiotensin-converting enzyme 2. Circulation. 2005; 111: 2605-2610.

11. Carly G, Ziegler K, et al. SARS-CoV-2 receptor ACE2 is an interferon-stimulated gene in human airway epithelial cells and is detected in specific cell subsets across tissues. Cell 2020. doi: 10.1016/j.cell.2020.04.035.

12. Rajendran P, Rengarajan T, Thangavel J, Nishigaki $Y$, Sakthisekaran D, Sethi G, Nishigaki I. The Vascular Endothelium and Human Diseases. Int J Biol Sci 2013; 9(10): 1057-1069.

13. Kade AK, Zanin SA, Gubareva EA, Turovaya AY, Bogdanova YA, Apsalyamova SO, Merzlyakova SN. Physiological functions of the vascular endothelium. Basic research. 2011; 11(3): 611-617.

14. Chatterjee S. Endothelial Mechanotransduction, Redox Signaling and the Regulation of Vascular Inflammatory Pathways. Front Physiol. 2018; 9: 524.

15. Ciceri F, Beretta L, Scandroglio AM, Colombo S, Landoni G, Ruggeri A, Peccatori J, D'Angelo A, De Cobelli F, Rovere-Querini P, Tresoldi M, Dagna L, Zangrillo A. Microvascular COVID-19 lung vessels obstructive thromboinflammatory syndrome (MicroCLOTS): an atypical acute respiratory distress syndrome working hypothesis. Crit Care Resusc. 2020; 22(2): 95-97.
16. Lai CC, Shih TP, Ko WC, Tang HJ, Hsueh PR. Severe acute respiratory syndrome coronavirus 2 (SARS-CoV2) and coronavirus disease-2019 (COVID-19): The epidemic and the challenges. Int $\mathrm{J}$ Antimicrob Agents. 2020; 55(3): 105924.

17. Special Expert Group for Control of the Epidemic of Novel Coronavirus Pneumonia of the Chinese Preventive Medicine Association. An update on the epidemiological characteristics of novel coronavirus pneumonia (COVID-19). Chin J Epidemiol. 2020; 41.

18. Zhou F, Yu T, Du R, Fan G, Liu Y, Liu Z, Xiang J, Wang Y, Song B, Gu X, Guan L, Wei Y, Li H, Wu X, Xu J, Tu $\mathrm{S}$, Zhang $\mathrm{Y}$, Chen $\mathrm{H}$, Cao B. Clinical course and risk factors for mortality of adult in patients with COVID-19 in Wuhan, China: a retrospective cohort study. Lancet. 2020 Mar 28;395(10229):1054-1062.

19. Liu W, Tao Z-W, Wang L, Yuan M-L, Liu K, Zhou L, Wei S, Deng Y, Liu J, Liu H-G, Yang M, Hu Y, Analysis of factors related to the clinical outcome in hospitalized patients with a new type of coronavirus infection. Chin Med J (Engl). 2020; 133(9): 1032-1038.

20. Alhazzani W, Møller MH, Arabi YM, Loeb M, Gong MN, Fan E, Oczkowski S, Levy MM, Derde L, Dzierba A, Du B, Aboodi M, Wunsch H, Cecconi M, Koh Y, Chertow DS, Maitland K, Alshamsi F, Belley-Cote E, Greco M, Laundy M, Morgan JS, Kesecioglu J, McGeer A, Mermel L, Mammen MJ, Alexander PE, Arrington A, Centofanti JE, Citerio G, Baw B, Memish ZA, Hammond N, Hayden FG, Evans L, Rhodes A. Surviving Sepsis Campaign: guidelines on the management of critically ill adults with Coronavirus Disease 2019 (COVID-19). Intensive Care Med. 2020; 46(5): 854887.

21. Guidelines for the management of critically ill adults with coronavirus disease 2019 (COVID-19), Translated by V.S. Gorokhovsky, M.B. Kutsego, A.A. Naumenko, V.D. Hunter, I.R. Cherkashina, https://rosomed.ru/documents/rukovodstvo-po-vedeniu-kriticheski-bolnyhvzroslyh-s-koronavirusnoi-boleznu-2019-covid-19-vperevode-na-russkii-yazyk (date of the application 21.04.2020).

22. Chousterman BG, Swirski FK, Weber GF. Cytokine storm and sepsis disease pathogenesis. Semin Immunopathol. 2017; 39: 517-528.

23. Chakraborty RK, Burns B. Systemic Inflammatory Response Syndrome. [Updated 2020 Apr 28]. In: StatPearls [Internet]. Treasure Island (FL): StatPearls Publishing; 2020 Jan-. Available from: https://www.ncbi.nlm.nih.gov/books/NBK547669/

24. Gusev EY, Chereshnev VA, Yurchenko LN. Systemic inflammation from the perspective of the theory of a typical pathological process. Cytokines and inflammation. 2007; 6(4): 9-21.

25. Clapp BR, Hingorani AD, Kharbanda RK, MohamedAli V, Stephens JW, Vallance P, MacAllister RJ. Inflammation-induced endothelial dysfunction involves reduced nitric oxide bioavailability and increased oxidant stress. Cardiovasc Res. 2004; 64: 172-8. 
26. Moshage H. Cytokines and the hepatic acute phase response. J Pathol. 1997; 181(3): 257-66.

27. Schalkwijk CG, Poland DCW, van Dijk W, Kok A, Emeis JJ, Drager AM, Doni A, van Hinsbergh VWM, Stehouwer CDA. Plasma concentration of c-reactive protein is increased in type i diabetic patients without clinical macroangiopathy and correlates with markers of endothelial dysfunction: evidence for chronic inflammation. Diabetologia. 1999; 42: 351-7.

28. Ye Q, Wang B, Mao J. The pathogenesis and treatment of the 'Cytokine Storm' in COVID-19. J Infect. 2020; 80(6): 607-13.

29. Bannenberg GL, Chiang N, Ariel A, Arita M, Tjonahen E, Gotlinger KH, Hong S, Serhan CN. Molecular Circuits of Resolution: Formation and Actions of Resolvins and Protectins. J Immunol. 2005; 174: 4345-55.

30. Norling LV, Dalli LL, Dalli J. Resolving Inflammation by using Nutrition Therapy: Roles for Specialized ProResolving Mediators. Curr Opin Clin Nutr Metab Care. 2017; 20(2): 145-152.

31. Serhan CN, Brain SD, Buckley CD, Gilroy DW, Haslett C, O’Neill LAJ, Perretti M, Rossi AG, Wallace JL. Resolution of inflammation: state of the art, definitions and terms. FASEB J. 2007; 21(2): 325-332.

32. Sugimoto MA, Sousa LP, Pinho V, Perretti M, Teixeira MM. Resolution of Inflammation: What Controls Its Onset? Front Immunol. 2016; 7: 160

33. Sansbury BE, Spite M. Resolution of Acute Inflammation and the Role of Resolvins in Immunity, Thrombosis and Vascular Biology. Circ Res. 2016; 119(1): 113-30.

34. Serhan CN. Treating inflammation and infection in the 21st century: new hints from decoding resolution mediators and mechanisms. FASEB J. 2017; 31(4): 1273-88.

35. Serhan CN, Yacoubian S, Yang R. Anti-Inflammatory and Pro-Resolving Lipid Mediators. Annu Rev Pathol. 2008; 3: 279-312.

36. Serhan CN. Resolution phase of inflammation: novel endogenous anti-inflammatory and proresolving lipid mediators and pathways. Annu Rev Immunol. 2007;25:101137. DOI:10,1146 nol.25.022106.141647.

37. Molfino A, Amabile MI, Monti M, Muscaritoli M. Omega-3 Polyunsaturated Fatty Acids in Critical Illness: Anti-Inflammatory, Proresolving, or Both? Oxid Med Cell Longev. 2017; 2017: 5987082.

38. Duvall MG, Levy BD. DHA- and EPA-derived resolvins, protectins, and maresins in airway inflammation, Eur J Pharmacol. 2016; 785: 144-155.

39. Papa ND, Pignataro F. The Role of Endothelial Progenitors in the Repair of Vascular Damage in Systemic Sclerosis. Front Immunol. 2018; 9:1383.

40. Maddox JF, Hachicha M, Takano T, Petasis NA, Fokin VV, Serhan CN. Lipoxin A4 stable analogs are potent mimetics that stimulate human monocytes and THP-1 cells via a G-protein-linked lipoxin A4 receptor. J Biol Chem. 1997; 272(11): 6972-8.

41. Guilford WJ, Parkinson JF. Second-generation beta-oxidation resistant 3-oxa-lipoxin A4 analogs. Prostaglandins Leukot Essent Fatty Acids. 2005; 73(3-4): 245-50.
42. Safety and Preliminary Efficacy of Lipoxin Analog BLXA4-ME Oral Rinse for the Treatment of Gingivitis (BLXA4), ClinicalTrials.gov Identifier: NCT02342691.

43. Faller S, Hoetzel A. Carbon monoxide in acute lung injury. Curr Pharm Biotechnol. 2012; 13(6): 777-86.

44. Shinohara M, Kibi M, Riley IR, Chiang N, Dalli J, Kraft BD, Piantadosi CA, Choi AM, Serhan CN. Cell-cell interactions and bronchoconstrictor eicosanoid reduction with inhaled carbon monoxide and resolvin D1. Am J Physiol Lung Cell Mol Physiol. 2014; 307(10): L746-57.

45. Dalli J, Kraft BD, Colas RA, Shinohara M, Fredenburgh LE, Hess DR, Chiang N, Welty-Wolf K, Choi AM, Piantadosi CA, Serhan CN. The Regulation of Proresolving Lipid Mediator Profiles in Baboon Pneumonia by Inhaled Carbon Monoxide. Am J Respir Cell Mol Biol. 2015; 53(3): 314-25.

46. Rossi AG, Sawatzky DA, Walker A, Ward C, Sheldrake TA, Riley NA, Caldicott A, Martinez-Losa M, Walker TR, Duffin R, Gray M, Crescenzi E, Martin MC, Brady HJ, Savill JS, Dransfield I, Haslett C. Cyclin-dependent kinase inhibitors enhance the resolution of inflammation by promoting inflammatory cell apoptosis. Nat Med. 2006; 12(9): 1056-64.

47. Dalli J, Norling LV, Montero-Melendez T, Federici Canova D, Lashin H, Pavlov AM, Sukhorukov GB, Hinds CJ, Perretti M. Microparticle alpha-2-macroglobulin enhances pro-resolving responses and promotes survival in sepsis. EMBO Mol Med. 2014; 6(1): 27-42.

48. Njock MS, Cheng HS, Dang LT, Nazari-Jahantigh M, Lau AC, Boudreau E, Roufaiel M, Cybulsky MI, Schober A, Fish JE. Endothelial cells suppress monocyte activation through secretion of extracellular vesicles containing antiinflammatory microRNAs. Blood. 2015; 125(20): 3202-12.

49. Wang J, Wang BJ, Yang JC, Wang MY, Chen C, Luo GX, He WF. Research advances in the mechanism of pulmonary fibrosis induced by coronavirus disease 2019 and the corresponding therapeutic measures. Zhonghua Shao Shang Za Zhi. 2020; 36(8): 691-7.

50. Zhang T, Sun LX, Feng RE. Comparison of clinical and pathological features between severe acute respiratory syndrome and coronavirus disease 2019. Zhonghua Jie He He Hu Xi Za Zhi. 2020; 43(6): 496-502.

51. Barton LM, Duval EJ, Stroberg E, Ghosh S, Mukhopadhyay S. COVID-19 Autopsies, Oklahoma, USA. Am J Clin Pathol. 2020; 153(6): 725-33.

52. Cho JG, Lee A, Chang W, Lee MS, Kim J. Endothelial to Mesenchymal Transition Represents a Key Link in the Interaction between Inflammation and Endothelial Dysfunction. Front Immunol. 2018; 9: 294.

53. Uddin M, Levy BD. Resolvins: natural agonists for resolution of pulmonary inflammation. Prog Lipid Res. 2011; 50(1): 75-88.

54. Al-Soudi A, Kaaij MH, Tas SW. Endothelial cells: From innocent bystanders to active participants in immune responses. Autoimmun Rev. 2017; 16(9): 951-62.

55. Kawai T, Akira S. Toll-like receptors and their crosstalk with other innate receptors in infection and immunity. Immunity. 2011; 34(5): 637-50. 
56. Salvador B, Arranz A, Francisco S, Córdoba L, Punzón C, Llamas MÁ, Fresno M. Modulation of endothelial function by Toll like receptors. Pharmacol Res. 2016; 108: 46-56.

57. Khakpour S, Wilhelmsen K, Hellman J. Vascular endothelial cell Toll-like receptor pathways in sepsis. Innate Immun. 2015; 21(8): 827-46.

58. Herzog C, Haun RS, Kaushal GP. Role of meprin metalloproteinases in cytokine processing and inflammation. Cytokine. 2019; 114: 18-25.

59. Muller WA. Transendothelial migration: unifying principles from the endothelial perspective. Immunol Rev. 2016; 273(1): 61-75.

60. Reglero-Real N, Colom B, Bodkin JV, Nourshargh S. Endothelial Cell Junctional Adhesion Molecules: Role and Regulation of Expression in Inflammation. Arterioscler Thromb Vasc Biol. 2016; 36(10): 2048-57.

61. Vestweber D. How leukocytes cross the vascular endothelium. Nat Rev Immunol. 2015; 15(11): 692-704.

62. Serhan CN. Novel Pro-Resolving Lipid Mediators in Inflammation Are Leads for Resolution Physiology, Nature. 2014; 510(7503): 92-101.

63. Serhan CN, Chiang N, Dalli J. The resolution code of acute inflammation: Novel pro-resolving lipid mediators in resolution. Semin Immunol. 2015; 27(3): 200-15. Johansson PI, Stensballe J, Rasmussen LS, Ostrowski SR.

64. A high admission syndecan-1 level, a marker of endothelial glycocalyx degradation, is associated with inflammation, protein $\mathrm{C}$ depletion, fibrinolysis, and increased mortality in trauma patients. Ann Surg. 2011; 254(2): 194-200.

65. Neves FM, Meneses GC, Sousa NE, Menezes RR, Parahyba MC, Martins AM, Libório AB. Syndecan-1 in Acute Decompensated Heart Failure--Association With Renal Function and Mortality. Circ J. 2015; 79(7): 1511-9.

66. Sieve I, Münster-Kühnel AK, Hilfiker-Kleiner D. Regulation and function of endothelial glycocalyx layer in vascular diseases. Vascul Pharmacol. 2018; 100: 26-33.

67. Incalza MA, D'Oria R, Natalicchio A, Perrini S, Laviola L, Giorgino F. Oxidative stress and reactive oxygen species in endothelial dysfunction associated with cardiovascular and metabolic diseases. Vascul Pharmacol. 2018; 100: 1-19.

68. Nourshargh S, Alon R. Leukocyte migration into inflamed tissues. Immunity. 2014; 41(5): 694-707.

69. Pober JS, Cotran RS. The role of endothelial cells in inflammation. Transplantation. 1990; 50(4): 537-44.

70. Pober JS, Sessa WC. Evolving functions of endothelial cells in inflammation. Nat Rev Immunol. 2007; 7(10): 803-15.

71. London NR, Zhu W, Bozza FA, Smith MC, Greif DM, Sorensen LK, Chen L, Kaminoh Y, Chan AC, Passi SF, Day CW, Barnard DL, Zimmerman GA, Krasnow MA, Li DY. Targeting Robo4-dependent Slit signaling to survive the cytokine storm in sepsis and influenza. Sci Transl Med. 2010; 2(23): 23ra19.
72. Escher R, Breakey N, Lämmle B. Severe COVID-19 infection associated with endothelial activation. Thromb Res. 2020; 190: 62.

73. Hunt B, Retter A, McClintock C. Practical guidance for the prevention of thrombosis and management of coagulopathy and disseminated intravascular coagulation of patients infected with COVID-19.

74. Kollias A, Kyriakoulis KG, Dimakakos E, Poulakou G, Stergiou GS, Syrigos K. Thromboembolic risk and anticoagulant therapy in COVID-19 patients: emerging evidence and call for action. Br J Haematol. 2020; 189(5): 846-847.

75. Spyropoulos AC, Ageno W, Barnathan ES. Hospitalbased use of thromboprophylaxis in patients with COVID-19. Lancet. 2020; 395(10234): e75.

76. Fan H, Goodwin AJ, Chang E, Zingarelli B, Borg K, Guan S, Halushka PV, Cook JA. Endothelial progenitor cells and a stromal cell-derived factor- $1 \alpha$ analogue synergistically improve survival in sepsis. Am J Respir Crit Care Med. 2014; 189(12): 1509-19.

77. Halaidych OV, Freund C, van den Hil F, Salvatori DCF, Riminucci M, Mummery CL, Orlova VV. Inflammatory Responses and Barrier Function of Endothelial Cells Derived from Human Induced Pluripotent Stem Cells. Stem Cell Reports. 2018 May 8;10(5):1642-56.

78. Votrin SV, Vorobyev SI, Bolevich SB, Use of perfluorocarbon based blod substitute perftoran in correction of hypoxia dyring acute anemia in animals. Ser J Exp Clin Res. 2019; 20(3): 245-50.

79. Vorobyov SI, Moiseenko OM, Belyaev BL, Srednyakov VA, Luzganov YuV. Colloid-chemical and medico-biological characteristics of the perfluorocarbon Ftoremulsion III. Pharm Chem J. 2009; 43(5): 267-73.

80. Vorobyov SI. Perfluorocarbon blood-replacing emulsions of the 1st and 2nd generation. Pharm Chem J. 2009; 43(4): 30-40. 